\title{
Modulation of the mesolimbic dopamine system by leptin
}

\author{
Darren M. Opland ${ }^{1,3}$, Gina M. Leinninger ${ }^{1}$, and Martin G. Myers Jr. ${ }^{1,2,3,4}$ \\ ${ }^{1}$ Division of Metabolism, Endocrinology and Diabetes, Department of Internal Medicine, \\ University of Michigan, Ann Arbor, MI 48109 \\ 2 Department of Molecular and Integrative Physiology, University of Michigan, Ann Arbor, MI \\ 48109
}

${ }^{3}$ Program in Neuroscience, University of Michigan, Ann Arbor, MI 48109

\section{SUMMARY}

Nutritional status modulates many forms of reward-seeking behavior, with caloric restriction increasing the drive for drugs of abuse as well as for food. Understanding the interactions between the mesolimbic dopamine (DA) system (which mediates the incentive salience of natural and artificial rewards) and the neural and hormonal systems that sense and regulate energy balance is thus of significant importance. Leptin, which is produced by adipocytes in proportion to fat content as a hormonal signal of long-term energy stores, acts via its receptor (LepRb) on multiple populations of central nervous system neurons to modulate neural circuits in response to body energy stores. Leptin suppresses feeding and plays a central role in the control of energy balance. In addition to demonstrating that leptin modulates hypothalamic and brainstem circuits to promote satiety, recent work has begun to explore the mechanisms by which leptin influences the mesolimbic DA system and related behaviors. Indeed, leptin diminishes several measures of drug and food reward, and promotes a complex set of changes in the mesolimbic DA system. While many of the details remain to be worked out, several lines of evidence suggest that leptin regulates the mesolimbic DA system via multiple neural pathways and processes, and that distinct sets of LepRb neurons each modulate unique aspects of the mesolimbic DA system and behavior in response to leptin.

\section{Keywords}

Leptin receptor; hypothalamus; feeding; obesity; ventral tegmental area; striatum; reward

\section{Energy balance and reward behavior}

While food has been used to modify behavior (e.g., to train animals) since before recorded history, mechanistic study of the pathways linking feeding and motivation is relatively recent. Behaviorist Edward Thorndike used food reward to motivate hungry animals learning to escape from early operant chambers (Thorndike, 1898), suggesting that incentive properties of food could aid in directing learning processes. In the $20^{\text {th }}$ century Clark Hull proposed Drive Theory (Hull, 1943), suggesting that an organism's overall motivation to

\footnotetext{
${ }^{4}$ Correspondence: Martin G. Myers, Jr., M.D., Ph.D., Division of Metabolism, Endocrinology and Diabetes, Department of Medicine, University of Michigan Medical School, 5560 MSRB II/0678, 1150 W. Medical Center Dr., Ann Arbor, MI 48109, PH: 734-647-9515, Fax: 734-936-6684, mgmyers@umich.edu.

Publisher's Disclaimer: This is a PDF file of an unedited manuscript that has been accepted for publication. As a service to our customers we are providing this early version of the manuscript. The manuscript will undergo copyediting, typesetting, and review of the resulting proof before it is published in its final citable form. Please note that during the production process errors may be discovered which could affect the content, and all legal disclaimers that apply to the journal pertain.
} 
obtain a reward is controlled by 3 factors: previous experience with the reward, size or value of the reward, and a separate overall drive component. This potentially dissociable drive component could be modulated by factors like deprivation, placing energy balance in context as a powerful behavioral modulator.

This link between nutritional status and reward is, if anything, more relevant than ever today. Not only does food restriction enhance motivation for (and relapse to) drugs of abuse, underlining the importance of this interaction for the understanding of addiction, but the reward value of food itself promotes overeating and likely contributes to the development and maintenance of obesity (Kelley et al., 2005; Kelley and Berridge, 2002). Obesity is a major risk factor for the development of Type 2 diabetes, cardiovascular disease, and cancer. Indeed, obesity and Type 2 diabetes represent global health threats that predispose millions of individuals to reduced life expectancy and incur $\$ 117$ billion in annual health care costs in the U.S. alone (Narayan et al., 2003; Ogden et al., 2006; Tierney et al., 2006). The current high rate of obesity in developed nations reflects an environment in which physical activity is diminished relative to past norms, in the face of plentiful, accessible food that is highly palatable and rewarding. Pharmacologic therapies to decrease appetite would be useful in treating obesity, diabetes, and related metabolic disorders, but our limited understanding of the neural and molecular mechanisms that regulate these processes has hindered the development of truly effective long-term therapies. Hence, it will be crucial to understand the systems that link energy balance to reward, and especially food reward, as we seek to define mechanisms that drive overeating and obesity.

\section{The regulation of energy intake and expenditure}

Animals regulate and maintain energy homeostasis over the long term: body adiposity is generally controlled within a given range for each individual, and alteration in energy stores provokes a countermanding response (Ahima et al., 2000). Not only does weight loss provoke increased feeding and decreased energy utilization, but forced overfeeding blunts volitional food intake and increases metabolic energy expenditure. Within energy balance, there are two overarching control variables-energy intake and energy expenditure. Overall energy expenditure includes basal metabolic rate, which is set by hormones such as thyroid hormone (among others), as well as the autonomic nervous system. Activity also contributes to energy utilization, as does the expenditure of energy on other functions, such as reproduction, lactation, etc. Decreased energy (fat) stores diminish energy utilization via each of these processes in order to maintain energy homeostasis.

The other side of the coin, energy intake, is mediated solely by the uptake of calories through eating and drinking. Many variables influence the amount of food consumed, however, including recent food intake, stomach distension, time of day, the perceived palatability of food, illness, etc (Berthoud, 2004). Broadly speaking, however, two processes control feeding-satiation, which causes meal termination, and the incentive salience of food that promotes the initiation and continuation of feeding. Both of these processes are influenced by energy balance-not only does weight loss delay satiation during meals, but it increases the incentive value of food measured in several ways, including the amount of work one is willing to perform in order to obtain food.

In 1954 Edward Stellar put forth the Dual Control Theory of Feeding suggesting that distinct brain regions, the ventromedial hypothalamus (containing the Arcuate (ARC) and ventromedial hypothalamic (VMN) nuclei) and lateral hypothalamic area (LHA) represented opposing "satiety" and "hunger" centers in the brain, respectively (Stellar, 1954). Lesions of the LHA cause animals to stop feeding and lose weight, while lesions of the satiety center promote hyperphagia and rapid weight gain (Teitelbaum and Stellar, 1954). It is now clear 
that other regions contribute to each of these processes: for instance, important signals from additional hypothalamic centers, as well as the hindbrain, contribute to satiety (Berthoud, 2006; Grill, 2006; Myers et al., 2009). Furthermore, while the LHA is clearly important to feeding behavior, the early LHA lesion studies disrupted the medial forebrain bundle, through which course the axons from dopamine-(DA)-containing midbrain neurons that appertain to the mesolimbic DA system (Kelley et al., 2005).

The mesolimbic DA system-encompassing DA neurons in the ventral tegmental area (VTA) plus their projections and neural targets in the striatum, amygdala, prefrontal cortex, and elsewhere-mediates the incentive salience of food and other rewards (Figlewicz and Benoit, 2009; Kelley and Berridge, 2002; Nestler, 2005). The reinforcing and addictive properties of both natural rewards (e.g., food, sex) and artificial rewards (drugs of abuse) are generally mediated by their effects on the mesolimbic DA system. Interestingly, feeding status and body energy stores modulates the reward value of reinforcers other than food: Caloric restriction not only increases the incentive salience of food, but promotes drug-taking, relapse to drug-taking, and the amount of work an animal will do to obtain drugs (Hao et al., 2006; Kelley and Berridge, 2002).

\section{Leptin mediates crucial signals of energy balance}

The signal or signals that convey the status of body energy stores to the CNS to control energy balance had remained unclear until the 1994 discovery of leptin-a peptide hormone that is produced by fat cells in approximate proportion to energy (triglyceride) content (Flier, 1995; Zhang et al., 1994). Mice null for leptin (ob/ob) display hyperphagia and decreased energy expenditure (with diminished thyroid and autonomic tone, infertility, etc.) in spite of their resulting obesity (high energy stores); these phenotypes are reversed by leptin, as are many similar alterations in calorie-restricted animals (Ahima et al., 1996; Friedman and Halaas, 1998). Thus, leptin levels serve as a crucial signal from adipose tissue to convey the status of long-term body energy stores and control feeding and energy expenditure.

Much of leptin action is mediated in the brain, where leptin acts via its receptor (LepRb) on the surface of specific populations of neurons (Cohen et al., 2001; de Luca et al., 2005). Leptin modulates a variety of neural systems in concert with energy balance. Leptin action via ARC, VMH, and brainstem LepRb neurons (along with other sets of leptin-responsive neurons) promotes satiety and permits energy expenditure via a variety of systems (Grill, 2006; Myers et al., 2009; van de et al., 2008). Other LepRb neurons, potentially including those in the ventral premammillary nucleus (PMv) of the hypothalamus, contribute to the control of reproduction (Hill et al., 2008; Leshan et al., 2009).

Leptin also contributes to the regulation of reward. Leptin attenuates responding for lateral hypothalamic self stimulation (LHSS) (Fulton et al., 2004; Fulton et al., 2000)-electrical stimulation of the LHA that presumably causes release of dopamine to the nucleus accumbens (NAc, the striatal structure most closely associated with reward acquisition in operant paradigms). Leptin also attenuates conditioned place preference (CPP) to sucrose in food-restricted rats (Figlewicz et al., 2004; Figlewicz et al., 2001) and decreases responding for sucrose on a progressive ratio operant paradigm (Figlewicz et al., 2006). Additionally, leptin blunts the reinforcing properties of several drugs of abuse in rodent models (Hao et al., 2004; Shalev et al., 2001). Together these studies suggest that leptin suppresses the incentive value of a variety of natural and artificial rewards; one proposed mechanism for this finding is that leptin might suppress mesolimbic DA release (Figlewicz and Benoit, 2009). Indeed, loss of mesolimbic DA abrogates feeding in normally hyperphagic $o b / o b$ 
(leptin-null) mice (Szczypka et al., 2000), and leptin decreases both basal and feedingevoked extracellular dopamine levels in the NAc of rats (Krugel et al., 2003).

In addition to these classical reward and feeding behaviors, leptin also modulates other behaviors associated with the mesolimbic DA system: Mice with low leptin levels display a variety of depressive and anxiety behaviors, and leptin treatment reverses these (Liu et al., 2009; Lu et al., 2006). Evidence from humans also suggests the importance of leptin in modulating the mesolimbic DA system and reward behaviors. Both leptin-deficient and calorically-restricted, weight-reduced human patients display increased hedonic drive for food, which is reversed by leptin; functional imaging studies have revealed that this leptin treatment alters the activity of a number of brains areas associated with reward and the mesolimbic DA system (Farooqi et al., 2007; Rosenbaum et al., 2008). Interestingly, obesity in humans is closely associated with the increased occurrence of mood and anxiety disorders (Simon et al., 2006).

\section{LepRb-expressing VTA neurons}

To understand how leptin might modulate mesolimbic DA function, a number of investigators examined the possibility of LepRb-expressing neurons in the mesolimbic DA system, revealing the expression of LepRb in a subset of DA neurons in the VTA, the source of mesolimbic DA cell bodies, as well as in the substantia nigra (SN) (Figlewicz, 2003). Hommel, et al., utilized a number of approaches to examine the potential roles for VTA leptin action in the regulation of feeding and mesolimbic DA function (Hommel et al., 2006). Direct leptin infusion to the VTA decreased food intake. Also, siRNA-mediated knockdown of LepRb expression in the VTA increased food intake and sensitivity to food reward, as measured with sucrose preference testing. Leptin was found to modestly hyperpolarize VTA DA neurons, as well. Thus, an emerging model suggested that leptin might directly inhibit VTA LepRb-expressing DA neurons to mediate the effects of leptin on the mesolimbic DA system (Figlewicz and Benoit, 2009; Hommel et al., 2006).

\section{Multiple distinct effects of leptin on the mesolimbic DA system}

Work from several decades ago, prior to the description of leptin and its receptor, had examined mesolimbic DA-mediated behaviors in the spontaneously obese Zucker $f a / f a$ ratthe phenotype of which is now known to stem from a mutation in the gene encoding the leptin receptor (Chua et al., 1996). In operant conditioning paradigms, these animals pressed levers for food at a much greater rate and consumed more food when the number of lever presses per food reward was low-consistent with the dramatic hyperphagia of these animals. Interestingly, however, the fa/fa rats stopped pressing the lever for food much earlier when response ratios were raised (i.e., when animals had to work hard to obtain the food reward (Greenwood et al., 1974). This result reveals the apparently decreased incentive salience of food in leptin receptor deficient animals, suggesting decreased striatal DA in the absence of leptin action. Furthermore, this result is unlikely to result solely from the obesity of these animals, since animals with genetic or lytic lesions of ventromedial hypothalamic pathways demonstrated increased rates of responding under a variety of reinforcement paradigms (Beatty, 1973; Greenwood et al., 1974; Hoebel and Teitelbaum, 1962; Vasselli et al., 1980).

Indeed, Fulton, et al., directly examined the function of the mesolimbic DA system in $o b / o b$ animals, demonstrating that the VTA of these animals contains less tyrosine hydroxylase ( $\mathrm{TH}$; the rate-limiting enzyme in DA synthesis), and that DA content is decreased in the VTA and NAc of these animals (Fulton et al., 2006). Consistent with the attenuated operant responding for food by the $f a / f a$ animals and the decreased mesolimbic DA content of the $o b / o b$ animals, the $o b / o b$ mice also demonstrate a severely blunted response to the DAreleasing drug, amphetamine (Fulton et al., 2006). Several days of systemic leptin treatment 
reversed the changes in TH expression, DA content, and amphetamine responsiveness of these animals. Consistent with these data, Roseberry, et al., while unable to detect effects of direct leptin action on the firing of VTA neurons, demonstrated decreased vesicular DA stores in VTA DA neurons of $o b / o b$ mice (Roseberry et al., 2007).

Thus, some data suggest that direct leptin action on LepRb-expressing VTA neurons controls food intake and reward, perhaps by decreasing the firing of VTA DA neurons. Leptin deficiency also decreases overall DA levels in the VTA and NAc, and these changes are restored by leptin, suggesting a role for leptin in the modulation of mesolimbic DA content, as well. Several reasonable explanations have been offered for these superficially opposing effects of leptin-including the potential for compensatory changes stemming from long-term leptin deficiency in ob/ob animals. It is important to note, however, that the firing of VTA DA neurons and the DA content of these neurons represent essentially different variables with potentially distinct outcomes. It is thus not unreasonable to suppose that leptin controls each of these variables without these effects necessarily cancelling each other. Furthermore, if we are to accept the data at face value, it seems that leptin controls at least two distinct variables in mesolimbic DA system function.

\section{A leptin-regulated LHA circuit controls mesolimbic DA content}

A number of lines of evidence link the LHA to the control of the mesolimbic DA system, including the reinforcing potential of electrical stimulation of the LHA and the apathetic nature of animals with LHA lesions (Kelley et al., 2005; Shizgal et al., 2001). While some of these effects could be attributable to mesolimbic fibers of passage that course through the LHA, it is also clear that multiple groups of LHA neurons project to major mesolimbic centers to control DA action and reward (DiLeone et al., 2003; Harris et al., 2005; Kelley et al., 2005). Among other, less-well characterized neural populations, the LHA contains large populations of widely-projecting neurons that express melanin concentrating hormone $(\mathrm{MCH})$ or orexin (OX) (DiLeone et al., 2003; Ludwig et al., 1998). Among their other projections, $\mathrm{MCH}$ neurons innervate the NAc to promote feeding. Some OX neurons innervate the VTA, and acute OX injection promotes feeding, as well as modulating DA neurons and the incentive value of drugs of abuse. While some opposite effects are observed in mice null for OX signaling (Funato et al., 2009; Hara et al., 2005), OX clearly promotes important effects on the mesolimbic DA system.

Recent work from our laboratory revealed a set of LepRb-expressing LHA neurons that are distinct from MCH and OX cells (Leinninger et al., 2009). Several lines of evidence suggest potentially important roles for these LHA LepRb neurons in feeding and the regulation of the mesolimbic DA system. In addition to projecting locally within the LHA, many of these LHA LepRb neurons directly innervate the VTA. Furthermore, intra-LHA leptin treatment of $o b / o b$ animals decreases feeding, while promoting VTA TH expression and increasing NAc DA content. In contrast, intra-VTA leptin fails to modulate TH expression. Thus, leptin action via LHA LepRb neurons appears to represent a major controller of overall mesolimbic DA content. The effect of LHA leptin action on the firing of VTA DA neurons remains to be examined.

\section{Potential distinct roles for midbrain LepRb neurons}

DA neurons in the VTA project to numerous brain regions, including limbic structures such as the extended amygdala, cortical targets in the prefrontal cortex, and the hippocampus, in addition to their striatal targets such as the NAc (Figlewicz and Benoit, 2009; Kelley et al., 2005; Nestler, 2005). Alternately-projecting midbrain DA neurons have recently been subdivided into distinct populations based on their VTA location and different electrophysiological properties (Bjorklund and Dunnett, 2007; Ikemoto, 2007; Lammel et 
al., 2008). Since VTA LepRb neurons account for a minority of DA neurons $(<10 \%)$, we examined the possibility that VTA LepRb neurons represent a specialized subset of VTA neurons, distinct in their projection patterns, as well as in their expression of LepRb. Indeed, our anterograde and retrograde tracing data reveal that VTA LepRb neurons densely innervate extended central amygdala $(\mathrm{CeA})$ structures, but send few projections to the NAc (Leshan et al., 2010). These data are consistent with a role for VTA LepRb neurons in the control of specific aspects of mesolimbic DA function specific to the CeA. Since the CeA is well-known for its role in mediating anxiety-like behaviors (Hunter et al., 2007), it is possible that VTA LepRb neurons subserve this specific function.

\section{Summary and future directions}

Energy balance represents a crucial modulator of motivation and the mesolimbic DA system, and leptin, a major signal of long-term energy balance, modulates the response to food and non-food rewards. At a molecular level, leptin appears to play multiple roles in the mesolimbic DA system, potentially inhibiting VTA DA neurons, as well as promoting the expression of TH and the production of DA within the VTA $\rightarrow$ NAc circuit. The neural mechanisms by which leptin controls the mesolimbic DA system also appear diverse: LepRb-expressing VTA DA neurons may play a specific role in the control of extended CeA function, while LHA LepRb neurons contribute to the modulation of TH and DA levels in the VTA $\rightarrow$ NAc circuit. Since only a few variables in mesolimbic DA function have been examined for regulation by leptin, it is likely that there remain other uncharacterized functions of leptin and LepRb neurons in control of the mesolimbic DA system.

Other populations of LepRb neurons may play roles in the mesolimbic DA system and reward processing-including LepRb neurons of the substantia nigra (SN), linear raphe (RLi) and Edinger-Westphal nuclei adjacent to the VTA, among others. Clearly, leptin also modulates the mesolimbic DA system by less direct means, involving additional synapses. Indeed, lateral hypothalamic melanin concentrating hormone $(\mathrm{MCH})$ and orexin $(\mathrm{OX})$ neurons project to the NAc and VTA, respectively, and modulate the mesolimbic DA system and feeding (DiLeone et al., 2003; Harris et al., 2005; Kelley et al., 2005). Neither of these leptin-inhibited populations of LHA neurons express LepRb, however (Leinninger et al., 2009)(Leinninger et al., 2009b), and leptin must act trans-synaptically to regulate MCH and OX neurons.

Overall, the mechanisms by which energy balance and leptin contribute to the regulation of the mesolimbic DA system will be crucial to understand as we seek to discover mechanisms underlying food intake behaviors, as well as more general reward signaling, and may reveal potential targets for therapeutic intervention in a variety of disorders.

\section{Acknowledgments}

Supported by NIH DK078056, the Marilyn H Vincent Foundation, and grants from the American Diabetes Association and American Heart Association (to MGM), and an Obesity Society New Investigator Award (to GML).

\section{References}

Ahima RS, Prabakaran D, Mantzoros CS, Qu D, Lowell BB, Maratos-Flier E, Flier JS. Role of leptin in the neuroendocrine response to fasting. Nature. 1996; 382:250-252. [PubMed: 8717038]

Ahima RS, Saper CB, Flier JS, Elmquist JK. Leptin regulation of neuroendocrine systems. Front Neuroendocrinol. 2000; 21:263-307. [PubMed: 10882542]

Beatty WW. Influence of type of reinforcement on operant responding by rats with ventromedial lesions. Physiol Behav. 1973; 10:841-846. [PubMed: 4715811] 
Berthoud HR. Neural control of appetite: cross-talk between homeostatic and non-homeostatic systems. Appetite. 2004; 43:315-317. [PubMed: 15527935]

Berthoud HR. Homeostatic and non-homeostatic pathways involved in the control of food intake and energy balance. Obesity(SilverSpring). 2006; 14(Suppl 5):197S-200S.

Bjorklund A, Dunnett SB. Dopamine neuron systems in the brain: an update. Trends Neurosci. 2007; 30:194-202. [PubMed: 17408759]

Chua SC Jr, Chung WK, Wu-Peng XS, Zhang Y, Liu SM, Tartaglia L, Leibel RL. Phenotypes of mouse diabetes and rat fatty due to mutations in the OB (leptin) receptor. Science. 1996; 271:994996. [PubMed: 8584938]

Cohen P, Zhao C, Cai X, Montez JM, Rohani SC, Feinstein P, Mombaerts P, Friedman JM. Selective deletion of leptin receptor in neurons leads to obesity. J Clin Invest. 2001; 108:1113-1121. [PubMed: 11602618]

de Luca C, Kowalski TJ, Zhang Y, Elmquist JK, Lee C, Kilimann MW, Ludwig T, Liu SM, Chua SC Jr. Complete rescue of obesity, diabetes, and infertility in $\mathrm{db} / \mathrm{db}$ mice by neuron-specific LEPR-B transgenes. J Clin Invest. 2005; 115:3484-3493. [PubMed: 16284652]

DiLeone RJ, Georgescu D, Nestler EJ. Lateral hypothalamic neuropeptides in reward and drug addiction. Life Sci. 2003; 73:759-768. [PubMed: 12801597]

Farooqi IS, Bullmore E, Keogh J, Gillard J, O'Rahilly S, Fletcher PC. Leptin regulates striatal regions and human eating behavior. Science. 2007; 317:1355. [PubMed: 17690262]

Figlewicz DP. Adiposity signals and food reward: expanding the CNS roles of insulin and leptin. Am J Physiol Regul Integr Comp Physiol. 2003; 284:R882-R892. [PubMed: 12626355]

Figlewicz DP, Bennett J, Evans SB, Kaiyala K, Sipols AJ, Benoit SC. Intraventricular insulin and leptin reverse place preference conditioned with high-fat diet in rats. Behav Neurosci. 2004; 118:479-487. [PubMed: 15174925]

Figlewicz DP, Bennett JL, Naleid AM, Davis C, Grimm JW. Intraventricular insulin and leptin decrease sucrose self-administration in rats. Physiol Behav. 2006; 89:611-616. [PubMed: 17045623]

Figlewicz DP, Benoit SC. Insulin, leptin, and food reward: update 2008. Am J Physiol Regul Integr Comp Physiol. 2009; 296:R9-R19. [PubMed: 18945945]

Figlewicz DP, Higgins MS, Ng-Evans SB, Havel PJ. Leptin reverses sucrose-conditioned place preference in food-restricted rats. Physiol Behav. 2001; 73:229-234. [PubMed: 11399316]

Flier JS. The adipocyte: Storage depot or node on the energy information superhighway. Cell. 1995; 8:15-18. [PubMed: 7813011]

Friedman JM, Halaas JL. Leptin and the regulation of body weight in mammals. Nature. 1998; 395:763-770. [PubMed: 9796811]

Fulton S, Pissios P, Manchon RP, Stiles L, Frank L, Pothos EN, Maratos-Flier E, Flier JS. Leptin regulation of the mesoaccumbens dopamine pathway. Neuron. 2006; 51:811-822. [PubMed: 16982425]

Fulton S, Richard D, Woodside B, Shizgal P. Food restriction and leptin impact brain reward circuitry in lean and obese Zucker rats. Behav Brain Res. 2004; 155:319-329. [PubMed: 15364492]

Fulton S, Woodside B, Shizgal P. Modulation of brain reward circuitry by leptin. Science. 2000; 287:125-128. [PubMed: 10615045]

Funato H, Tsai AL, Willie JT, Kisanuki Y, Williams SC, Sakurai T, Yanagisawa M. Enhanced orexin receptor-2 signaling prevents diet-induced obesity and improves leptin sensitivity. Cell Metab. 2009; 9:64-76. [PubMed: 19117547]

Greenwood MR, Quartermain D, Johnson PR, Cruce JA, Hirsch J. Food motivated behavior in genetically obese and hypothalamic-hyperphagic rats and mice. Physiol Behav. 1974; 13:687-692. [PubMed: 4610605]

Grill HJ. Distributed neural control of energy balance: contributions from hindbrain and hypothalamus. Obesity(SilverSpring). 2006; 14(Suppl 5):216S-221S.

Hao J, Cabeza dV, Carr KD. Effects of chronic ICV leptin infusion on motor-activating effects of Damphetamine in food-restricted and ad libitum fed rats. Physiol Behav. 2004; 83:377-381. [PubMed: 15581659] 
Hao J, Cabeza dV, Pan Y, Carr KD. Effects of central leptin infusion on the reward-potentiating effect of D-amphetamine. Brain Res. 2006; 1087:123-133. [PubMed: 16600190]

Hara J, Yanagisawa M, Sakurai T. Difference in obesity phenotype between orexin-knockout mice and orexin neuron-deficient mice with same genetic background and environmental conditions. Neurosci Lett. 2005; 380:239-242. [PubMed: 15862893]

Harris GC, Wimmer M, Aston-Jones G. A role for lateral hypothalamic orexin neurons in reward seeking. Nature. 2005; 437:556-559. [PubMed: 16100511]

Hill JW, Elmquist JK, Elias CF. Hypothalamic pathways linking energy balance and reproduction. Am J Physiol Endocrinol Metab. 2008; 294:E827-E832. [PubMed: 18285524]

Hoebel BG, Teitelbaum P. Hypothalamic control of feeding and self-stimulation. Science. 1962; 135:375-377. [PubMed: 13907995]

Hommel JD, Trinko R, Sears RM, Georgescu D, Liu ZW, Gao XB, Thurmon JJ, Marinelli M, DiLeone RJ. Leptin receptor signaling in midbrain dopamine neurons regulates feeding. Neuron. 2006; 51:801-810. [PubMed: 16982424]

Hull, CL. Principles of behavior, an introduction to behavior theory. New York: D. Appleton-Century Company; 1943.

Hunter RG, Bellani R, Bloss E, Costa A, Romeo RD, McEwen BS. Regulation of CART mRNA by stress and corticosteroids in the hippocampus and amygdala. Brain Res. 2007; 1152:234-240. [PubMed: 17434149]

Ikemoto S. Dopamine reward circuitry: two projection systems from the ventral midbrain to the nucleus accumbens-olfactory tubercle complex. Brain Res Rev. 2007; 56:27-78. [PubMed: 17574681]

Kelley AE, Baldo BA, Pratt WE. A proposed hypothalamic-thalamic-striatal axis for the integration of energy balance, arousal, and food reward. J Comp Neurol. 2005; 493:72-85. [PubMed: 16255002]

Kelley AE, Berridge KC. The neuroscience of natural rewards: relevance to addictive drugs. J Neurosci. 2002; 22:3306-3311. [PubMed: 11978804]

Krugel U, Schraft T, Kittner H, Kiess W, Illes P. Basal and feeding-evoked dopamine release in the rat nucleus accumbens is depressed by leptin. Eur J Pharmacol. 2003; 482:185-187. [PubMed: 14660021]

Lammel S, Hetzel A, Hackel O, Jones I, Liss B, Roeper J. Unique properties of mesoprefrontal neurons within a dual mesocorticolimbic dopamine system. Neuron. 2008; 57:760-773. [PubMed: 18341995]

Leinninger GM, Jo YH, Leshan RL, Louis GW, Yang H, Barrera JG, Wilson H, Opland DM, Faouzi MA, Gong Y, et al. Leptin acts via leptin receptor-expressing lateral hypothalamic neurons to modulate the mesolimbic dopamine system and suppress feeding. Cell Metab. 2009; 10:89-98. [PubMed: 19656487]

Leshan RL, Louis GW, Jo YH, Rhodes CJ, Munzberg H, Myers MG Jr. Direct innervation of GnRH neurons by metabolic- and sexual odorant-sensing leptin receptor neurons in the hypothalamic ventral premammillary nucleus. J Neurosci. 2009; 29:3138-3147. [PubMed: 19279251]

Leshan RL, Opland DM, Louis GW, Leinninger GM, Patterson CM, Rhodes CJ, Munzberg H, Myers MG Jr. VTA Leptin Receptor Neurons Specifically Project to and Regulate CART Neurons of the Extended Central Amygdala. J Neurosci. 2010 In Press.

Liu J, Garza JC, Bronner J, Kim CS, Zhang W, Lu XY. Acute administration of leptin produces anxiolytic-like effects: a comparison with fluoxetine. Psychopharmacology (Berl). 2009

Lu XY, Kim CS, Frazer A, Zhang W. Leptin: a potential novel antidepressant. Proc Natl Acad Sci USA. 2006; 103:1593-1598. [PubMed: 16423896]

Ludwig DS, Mountjoy KG, Tatro JB, Gillette JA, Frederich RC, Flier JS, Maratos-Flier E. Melaninconcentrating hormone: a functional melanocortin antagonist in the hypothalamus. Am J Physiol. 1998; 274:E627-633. [PubMed: 9575823]

Myers MG Jr, Munzberg H, Leinninger GM, Leshan RL. The geometry of leptin action in the brain: more complicated than a simple ARC. Cell Metab. 2009; 9:117-123. [PubMed: 19187770]

Narayan KM, Boyle JP, Thompson TJ, Sorensen SW, Williamson DF. Lifetime risk for diabetes mellitus in the United States. JAMA. 2003; 290:1884-1890. [PubMed: 14532317] 
Nestler EJ. Is there a common molecular pathway for addiction? Nat Neurosci. 2005; 8:1445-1449. [PubMed: 16251986]

Ogden CL, Carroll MD, Curtin LR, McDowell MA, Tabak CJ, Flegal KM. Prevalence of overweight and obesity in the United States, 1999-2004. JAMA. 2006; 295:1549-1555. [PubMed: 16595758]

Roseberry AG, Painter T, Mark GP, Williams JT. Decreased vesicular somatodendritic dopamine stores in leptin-deficient mice. J Neurosci. 2007; 27:7021-7027. [PubMed: 17596451]

Rosenbaum M, Sy M, Pavlovich K, Leibel RL, Hirsch J. Leptin reverses weight loss-induced changes in regional neural activity responses to visual food stimuli. J Clin Invest. 2008; 118:2583-2591. [PubMed: 18568078]

Shalev U, Yap J, Shaham Y. Leptin attenuates acute food deprivation-induced relapse to heroin seeking. J Neurosci. 2001; 21:RC129. [PubMed: 11160414]

Shizgal P, Fulton S, Woodside B. Brain reward circuitry and the regulation of energy balance. Int J Obes Relat Metab Disord. 2001; 25(Suppl 5):S17-S21. [PubMed: 11840209]

Simon GE, Von Korff M, Saunders K, Miglioretti DL, Crane PK, van Belle G, Kessler RC. Association between obesity and psychiatric disorders in the US adult population. Arch Gen Psychiatry. 2006; 63:824-830. [PubMed: 16818872]

Stellar E. The physiology of motivation. Psychol Rev. 1954; 61:5-22. [PubMed: 13134413]

Szczypka MS, Rainey MA, Palmiter RD. Dopamine is required for hyperphagia in Lep(ob/ob) mice. Nat Genet. 2000; 25:102-104. [PubMed: 10802666]

Teitelbaum P, Stellar E. Recovery from the failure to eat produced by hypothalamic lesions. Science. 1954; 120:894-895. [PubMed: 13216188]

Thorndike E. Some Experiments on Animal Intelligence. Science. 1898; 7:818-824.

Tierney EF, Gregg EW, Narayan KM. Leading causes of death in the United States. JAMA. 2006; 295:383. [PubMed: 16434624]

van de WE, Leshan R, Xu AW, Balthasar N, Coppari R, Liu SM, Jo YH, MacKenzie RG, Allison DB, Dun NJ, et al. Collective and individual functions of leptin receptor modulated neurons controlling metabolism and ingestion. Endocrinology. 2008; 149:1773-1785. [PubMed: 18162515]

Vasselli JR, Cleary MP, Jen KL, Greenwood MR. Development of food motivated behavior in free feeding and food restricted Zucker fatty (fa/fa) rats. Physiol Behav. 1980; 25:565-573. [PubMed: 7208653]

Zhang Y, Proenca R, Maffei M, Barone M, Leopold L, Friedman JM. Positional cloning of the mouse obese gene and its human homologue. Nature. 1994; 372:425-432. [PubMed: 7984236] 